\title{
Dimethyl fumarate vs fingolimod following different pretreatments
}

\author{
A retrospective study
}

Lara Diem, MD, Ariadne Daponte, MD, Oliver Findling, MD, Andrei Miclea, MD, Myriam Briner, MD,

Anke Salmen, MD, Ralf Gold, MD, Constantinos Kilidireas, MD, Andrew Chan, MD,

Maria Elftheria Evangelopoulos, MD,* and Robert Hoepner, MD*

Correspondence

Dr. Findling

Neurol Neuroimmunol Neuroinflamm 2020;7:e660. doi:10.1212/NXI.0000000000000660

e660

Abstract

\section{Objective}

Despite frequent use of fingolimod (FTY) and dimethyl fumarate (DMF), studies comparing clinical efficacy and withdrawal rates of DMF and FTY concerning different pretreatment situations are rare. The aim of our study was to compare relapse occurrence and withdrawal rates of DMF and FTY in different pretreatment situations.

\section{Methods}

Patients from 4 European centers were retrospectively identified and followed until the 1st relapse after treatment start or if no relapse occurred for a maximum of 2 years. Cox regression analyses adjusted for relapsing-remitting MS (RRMS) disease duration, sex, and region were performed for the following pretreatment situations: treatment naive or injectables or DMF/ FTY or natalizumab.

\section{Results}

Seven hundred thirty-two patients with RRMS (female/male: 2.4:1.0; DMF n = 409, FTY n = $323)$ were analyzed. Compared with FTY-treated patients, DMF-treated patients discontinued treatment more frequently mainly because of side effects (DMF/FTY: 29.3\%/20.7\%). Clinical relapses occurred in $24.5 \%$ of the patients within 24 months. Survival analysis demonstrated that compared with FTY treatment, DMF treatment was associated with an adjusted hazard ratio (aHR) for occurrence of relapse of $1.9(95 \%$ CI 1.4-2.6, $p<0.001, \mathrm{n}=732)$. Stratification into pretreatment groups unmasked a higher relapse risk in DMF patients pretreated with natalizumab (aHR [95\% CI] 4.5 [1.9-10.8], $p=0.001, \mathrm{n}=122$ ) or to a lesser extend also in treatment-naive patients (aHR [95\% CI] 1.9 [1.01-3.6], $p=0.045, \mathrm{n}=230$ ). No differences were observed in patients pretreated with injectables or the respective other oral drug (injectables: $p>0.05, \mathrm{n}=341$; other oral: $p>0.05, \mathrm{n}=39$ ).

\section{Conclusions}

DMF treatment was associated with higher clinical disease activity compared with FTY treatment. A subgroup analysis suggested beneficial effects of FTY in treatment-naive and patients pretreated with natalizumab.

\footnotetext{
*These authors contributed equally to this work.
}

From the Department of Neurology (L.D., A.M., M.B., A.S., A.C., M.E.E., R.H.), Inselspital, Bern University Hospital and University of Bern, Freiburgstrasse, Bern, Switzerland; Department of Neurology (A.D., C.K., M.E.E.), Eginition University Hospital, National and Kapodistrian University of Athens, Greece; Department of Neurology (O.F.), Cantonal Hospital Aarau, Tellstrasse, Aarau, Switzerland; Department of Neurology (O.F.), Karl Landsteiner University of Health Sciences, Site Tulln, Austria; and Department of Neurology (R.G.), St. Josef Hospital Ruhr University Bochum, Germany.

Go to Neurology.org/NN for full disclosures. Funding information is provided the end of the article.

The Article Processing Charge was funded by the authors.

This is an open access article distributed under the terms of the Creative Commons Attribution-NonCommercial-NoDerivatives License 4.0 (CC BY-NC-ND), which permits downloading and sharing the work provided it is properly cited. The work cannot be changed in any way or used commercially without permission from the journal. 


\section{Glossary}

aHR = adjusted hazard ratio; DMF = dimethyl fumarate; FTY = fingolimod; NEDA-3 = no evidence of disease activity-3; RRMS = relapsing-remitting MS.

Fingolimod (FTY) and dimethyl fumarate (DMF) are oral immunotherapies approved to treat patients with relapsingremitting MS (RRMS). ${ }^{1,2}$ Several studies have retrospectively compared clinical efficacy between DMF and FTY, demonstrating mostly a similar efficacy. ${ }^{3-6}$ Moderate differences between DMF/FTY were present concerning MRI disease activity and treatment tolerability, which was superior in FTYtreated patients. In addition, focusing on the outcome parameter "no evidence of disease activity-3" (NEDA-3), which was reached in DMF- and FTY-treated patients with comparable frequencies, a subgroup analysis, however, unmasked a superiority of FTY in patients switching from self-injectable drugs to the respective oral substance. ${ }^{6}$ This different clinical efficacy was not present in treatment-naive patients. Stratification into other pretreatment groups (e.g., pretreatment with natalizumab or the other oral drug) is missing. ${ }^{6}$

Our study will provide real-world data comparing discontinuation rates and clinical efficacy of DMF and FTY concerning the following pretreatment situations: treatment naive, injectables, the other oral drug DMF or FTY, and natalizumab.

\section{Methods}

\section{Patient groups studied}

We conducted a retrospective observational study over 24 months including 732 patients with RRMS of the 4 participating European centers (figure) who had been treated with DMF $(n=409)$ or FTY $(n=323)$. Identification of eligible patients was performed using the following search terms "MS and fingolimod or Gilenya or FTY" in the centers Aarau, Athens, and Bern and "MS and Tecfidera or dimethyl fumarate or fumarate or DMF" in all 4 participating centers to search local clinical information systems within the following time frames for Bern, Aarau, and Athens January 2011December 2018 and for Bochum January 2011-January 2016. No additional selection criteria were set. All patients identified with this search algorithm were included. MS diagnosis was in accordance with the $2010 \mathrm{McD}$ onald criteria. ${ }^{7}$ Definition of clinical MS relapse followed national guidelines. The following variables were extracted from medical records: date of birth, year of MS diagnosis, sex, previous MS medication, date of the adverse event, date of drug withdrawal, date of treatment initiation of DMF or FTY, date of the 1st relapse under DMF or FTY treatment, or if no relapse during the 2-year follow-up occurred date of the last follow-up visit.

\section{Statistical analysis}

Categorical data are presented as frequencies and continuous data as means and $95 \%$ confidence intervals (95\% CI) and compared using for continuous variables Mann-Whitney test and for categorical variables $\chi^{2}$ test. Survival analyses with the outcome "clinical relapse" were performed using Cox regression analysis adjusted for sex, RRMS disease duration, and region (Switzerland vs Europe). Survival analysis was performed for different pretreatments: (1) treatment naive, (2) previous treatment with injectables (interferon or glatiramer acetate), (3) previous treatment with DMF or FTY, or (4) previous treatment with natalizumab. Level of significance was set to $p<0.05$.

\section{Ethical approvals}

The respective ethic committees Aarau (2016-02233), Bern (2017-01369), Eginition Hospital Athens (1272018-511), and Bochum (5408-15) approved the analysis.

\section{Data availability}

Anonymized source data are available on reasonable request via the corresponding author.

\section{Results}

Baseline demographics are shown in table 1 . The primary reason for beginning with FTY was disease activity (DMF: 71/409, $17.4 \%$ vs FTY: $108 / 323$, 33.4\%, $p<0.001$ ). Adverse events during previous immunotherapies were the main reason for beginning with DMF (DMF: 113/409, 27.6\% vs FTY: 58/323, $18.0 \%, p<0.001)$. Drug discontinuation was more common in DMF- than in FTY-treated patients (DMF: 120/409, 29.3\% vs FTY: $67 / 323,20.7 \%, p=0.008$ ). Adverse events were the most common reason for withdrawal (table 1). Despite clinical disease activity occurred in 20.4\%-27.6\% (FTY: 66/323 vs DMF: 113 / 409) of the patients, in only $33.6 \%-47.0 \%$ (DMF: $38 / 113$ vs FTY: 31/66) of these patients, disease activity let to FTY/DMF withdrawal (table 1). The mean time to the 1st relapse was shorter in DMF-treated patients (years mean [95\% CI]: DMF: 0.6 [0.5-0.6], $\mathrm{n}=113$ vs FTY: $1.0[0.8-1.1], \mathrm{n}=66 ; p<0.001$ ), and this differences was the highest in the group pretreated with injectables (years mean [95\% CI]: DMF: $0.6[0.3-0.7], \mathrm{n}=30$ vs FTY: 1.1 [0.9-1.3], $\mathrm{n}=42 ; p<0.001$, table 1 ).

Compared with patients treated with FTY, patients treated with DMF had a higher adjusted hazard ratio (aHR) for occurrence of clinical relapse (aHR [95\% CI] 1.9 [1.4-2.6], $p<$ $0.001, \mathrm{n}=732$, table 1 ). Stratification into pretreatment groups highlighted a higher relapse risk in DMF-treated patients pretreated with natalizumab (aHR [95\% CI] 4.5 [1.9-10.8], $p=$ $0.001, \mathrm{n}=122$, table 1 ) or to a lesser extent in treatment-naive patients (aHR [95\% CI] 1.9 [1.01-3.6], $p=0.045, \mathrm{n}=230$, table 1). No differences were observed in patients pretreated 


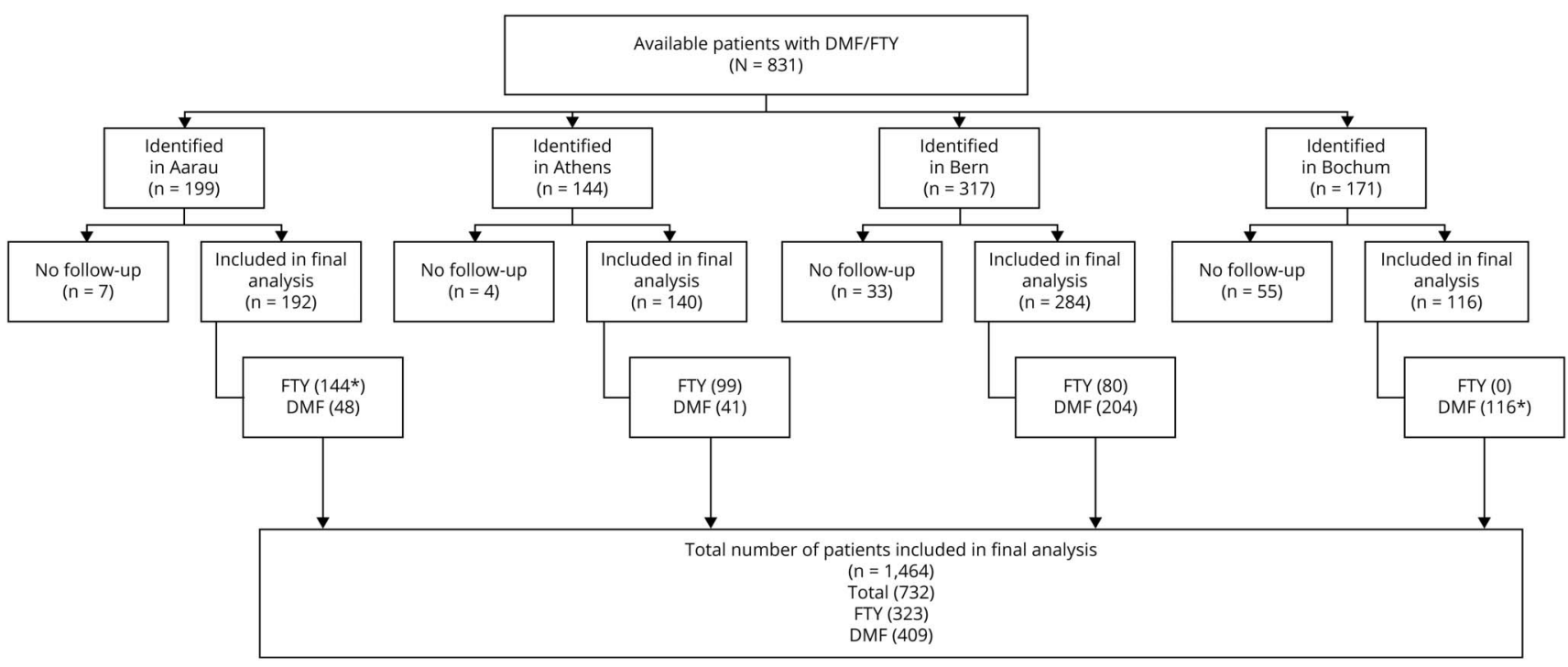

Some patients of this cohort included in (1) Diem et al. TAND 2018 doi: 10.1177/1756286418791103 and (2) Miclea et al. J Neurol 2016 doi: 10.1007/s00415016-8175-3. Locally used clinical information systems were i-pdos (Phoenix Technologies, Milpitas) in Bern, Orbis (Agfa HealthCare, Mortsel, Belgium) in Bochum, in-house "Demyelinating Diseases Database 1st Department of Neurology" in Athens, and KISIM (Cistec AG, Zürich, Switzerland) in Aarau. DMF = dimethyl fumarate; FTY = fingolimod.

with injectables or the respective other oral drug (injectables: $p$ $>0.05, \mathrm{n}=341$; other oral: $p>0.05, \mathrm{n}=39$, table 1 ).

\section{Discussion}

We present a comparison of discontinuation rates and clinical efficacy data of DMF- and FTY-treated patients with RRMS over a follow-up period of 24 months. Taking advantage of the FTY label as 1st-line MS treatment in Switzerland, this study provides a unique patient population for head-to-head comparison of the clinical efficacy of DMF vs FTY in different pretreatment situations including treatment-naive patients. ${ }^{8}$ In general, FTY appears to be less frequently withdrawn and clinically more effective in terms of relapse activity in our study. This increased clinical efficacy was present in treatment-naive and in patients pretreated with natalizumab, whereas patients pretreated with injectables or switching from DMF to FTY or vice versa demonstrated to have an equal clinical response to treatment.

In line with previous reports, we demonstrated that discontinuation was more common in DMF- than in FTY-treated patients with adverse drug events being the main reason for drug withdrawal. ${ }^{5}$ Concerning disease activity, previous studies reported an equal efficacy ${ }^{3,4}$ or a trend toward a higher efficacy of FTY compared with DMF. ${ }^{5,6}$ The latter was also present in our study; however, our work provides additional evidence for different drug efficacy in regard to previous immunotherapy. Patients switching from natalizumab and to a lesser degree also treatment-naive patients with MS benefitted from FTY in terms of the outcome "occurrence of relapse", whereas no differences for occurrence of relapses were seen in patients pretreated with injectables or the respective other oral drug.

Prosperini et al. ${ }^{6}$ found a superiority of FTY in patients pretreated with injectables, whereas-different to ours-this was not present in treatment-naive patients. Reasons for different findings may be the different end points used and the different drug labels of each study country. Prosperini et al. ${ }^{6}$ investigated NEDA-3 status, whereas our investigation purely focused on clinical relapses. Analysis of NEDA-3 status was not possible in our study because of different MRI protocols, frequencies of MRI assessments, and clinical visits between participating centers making a structured end point comparison for MRI and disability readouts prone to centrum biases.

The limitations of our retrospective study will be addressed in the following. Adjustment of the Cox regression analysis for each center was not possible because of small patient and event numbers in each single center, respectively (supplementary table 1, links.lww.com/NXI/A174), creating a limitation of our analysis. We therefore adjusted for region (Switzerland vs EU), as recommended in such cases by the European Medicine Agency. ${ }^{9}$ Adjustment for region is justified by the country-specific label of FTY considering 1st(Switzerland) vs 2nd-line treatment (Europe: Germany and Greece), which might have had the greatest influence on our analysis. ${ }^{10}$ Patients were identified in the centers using predefined terms to search the existing local clinical information systems (figure). No other selection criteria were set. Whether in general, the setting of university and large academic MS centers creates a selection bias, cannot be 
Table 1 Description of fingolimod $(n=323)$ or DMF $(n=409)$ treated patients and Cox regression models to predict clinical disease activity

\begin{tabular}{|c|c|c|c|}
\hline & FTY & DMF & $p$ Value \\
\hline $\mathrm{N}(\%)$ & $323(44.1)$ & 409 (55.9) & \\
\hline \multicolumn{4}{|l|}{ Centre, $\mathbf{N}(\%)$} \\
\hline Aarau & $144 / 323(44.6)$ & $48 / 409$ (11.7) & NA \\
\hline Athens & $99 / 323(30.7)$ & $41 / 409(10.0)$ & NA \\
\hline Bern & $80 / 323(24.8)$ & 204/409 (49.9) & NA \\
\hline Bochum & $0 / 323(0.0)$ & $116 / 409(28.4)$ & NA \\
\hline Female, $\mathbf{N}(\%)$ & $226 / 323(70.0)$ & 292/409 (71.4) & 0.674 \\
\hline Age in years, mean $(95 \% \mathrm{Cl})$ & $39.6(37.5-40.0)$ & $40.0(38.8-41.2)$ & 0.271 \\
\hline Disease duration in $\mathrm{y}$, mean $(95 \% \mathrm{Cl})$ & $6.8(6.1-7.5)$ & $5.9(5.7-6.6)$ & 0.001 \\
\hline \multicolumn{4}{|l|}{ MS treatment before DMF or FTY, $\mathrm{N}(\%)$} \\
\hline Treatment naive & $66 / 323(20.4)$ & $164 / 409(40.1)$ & $<0.001$ \\
\hline Injectables & $183 / 323(56.7)$ & $158 / 409(38.6)$ & $<0.001$ \\
\hline DMF & $12 / 323(3.7)$ & NA & NA \\
\hline Fingolimod & NA & $27 / 409(6.6)$ & NA \\
\hline Natalizumab & 62/323 (19.2) & $60 / 409(14.7)$ & 0.103 \\
\hline \multicolumn{4}{|l|}{ Primary reasons for beginning with DMF or FTY, $\mathbf{N}(\%)$} \\
\hline PML risk during NTZ & $79 / 323(24.5)$ & $52 / 409(12.7)$ & $<0.001$ \\
\hline Medication adverse effects & $58 / 323(18.0)$ & $113 / 409(27.6)$ & $<0.001$ \\
\hline Disease activity & $108 / 323(33.4)$ & $71 / 409(17.4)$ & $<0.001$ \\
\hline Postpregnancy & $1 / 323(0.3)$ & $1 / 409(0.2)$ & 0.980 \\
\hline Treatment naive & $66 / 323(20.4)$ & $162 / 409(39.6)$ & $<0.001$ \\
\hline Unknown & $11 / 323(3.4)$ & $10 / 409(2.4)$ & 0.439 \\
\hline Discontinuation of DMF/FTY, $\mathrm{N}(\%)$ & $67 / 323(20.7)$ & $120 / 409(29.3)$ & 0.008 \\
\hline Disease activity & $31 / 323(9.6)$ & $38 / 409(9.3)$ & 0.888 \\
\hline Medication adverse effects & $27 / 323(8.4)$ & $64 / 409(15.6)$ & 0.005 \\
\hline Pregnancy & $4 / 323(1.2)$ & $9 / 409(2.2)$ & 0.328 \\
\hline Unknown & $5 / 323(1.5)$ & $9 / 409(2.2)$ & 0.522 \\
\hline Mean time to discontinuation of DMF/FTY, y $(95 \% \mathrm{Cl})$ & $1.5(1.2-1.8)$ & $0.8(0.7-1.0)$ & $<0.001$ \\
\hline Treatment naive & $0.8(0.5-1.1)$ & $0.7(0.5-0.9)$ & 0.157 \\
\hline Injectables & $2.0(1.5-2.5)$ & $1.1(0.7-1.4)$ & 0.005 \\
\hline Other oral (e.g., DMF $\rightarrow$ FTY) & $1.1(0.5-1.7)$ & $1.0(0.2-1.7)$ & 0.307 \\
\hline Natalizumab & $0.8(0.3-1.5)$ & $0.8(0.3-1.1)$ & 0.905 \\
\hline Clinical relapse within $12 \mathrm{mo}, \mathrm{N}(\%)$ & $37 / 323(11.5)$ & $95 / 409(23.2)$ & $<0.001$ \\
\hline Clinical relapse within 24 mo, N (\%) & $66 / 323(20.4)$ & $113 / 409(27.6)$ & 0.025 \\
\hline Mean time to first relapse in y, mean $(95 \% \mathrm{Cl})$ & $1.0(0.8-1.1)$ & $0.6(0.5-0.6)$ & $<0.001$ \\
\hline Treatment naive & $0.8(0.5-1.1)$ & $0.6(0.5-0.7)$ & 0.375 \\
\hline Injectables & $1.1(0.9-1.3)$ & $0.6(0.3-0.7)$ & $<0.001$ \\
\hline
\end{tabular}


Table 1 Description of fingolimod $(n=323)$ or DMF $(n=409)$ treated patients and Cox regression models to predict clinical disease activity (continued)

\begin{tabular}{|c|c|c|c|}
\hline & FTY & DMF & $p$ Value \\
\hline Other oral (e.g., DMF $\rightarrow$ FTY) & $0.9(-1.1-3.1)$ & $0.6(0.1-1.2)$ & 0.865 \\
\hline \multirow[t]{2}{*}{ Natalizumab } & $0.5(0.0-3.0)$ & $0.4(0.2-0.6)$ & 0.979 \\
\hline & aHR $(95 \% \mathrm{Cl})$ & $\mathbf{N}$ & $p$ Value \\
\hline All patients & $1.9(1.4-2.6)$ & 732 & $<0.001$ \\
\hline Treatment naive & $1.9(1.01-3.6)$ & 230 & 0.045 \\
\hline Injectables & $1.5(0.9-2.5)$ & 341 & 0.085 \\
\hline Other oral (e.g., DMF $\rightarrow$ FTY) & $1.4(0.2-8.3)$ & 39 & 0.736 \\
\hline Natalizumab & $4.5(1.9-10.8)$ & 122 & 0.001 \\
\hline
\end{tabular}

Abbreviations: aHR = adjusted hazard ratio; DMF = dimethyl fumarate; DMT = disease-modifying treatment; EU = European Union; FTY = fingolimod; injectables = interferon or glatiramer acetate; NA = not applicable; NTZ = natalizumab; PML = progressive multifocal leukoencephalopathy.

Statistics: for continuous variables, the Mann-Whitney test was used, and for categorical variables, the $\chi^{2}$ test was used. Cox regression was adjusted for sex, disease duration, and region (Switzerland vs EU). aHRs are displayed for DMF compared with fingolimod. Significant $p$ values are written in bold letters. Clinical information systems in use were i-pdos (Phoenix Technologies, Milpitas) in Bern, Orbis (Agfa HealthCare, Mortsel, Belgium) in Bochum, in-house “Demyelinating Diseases Database of 1st Department of Neurology" in Athens, and KISIM (Cistec AG, Zürich, Switzerland) in Aarau.

sufficiently answered, and should be kept in mind when interpreting our data.

In addition, other limitations are the relatively small sample size in the group pretreated with DMF or FTY and the nonstandardized treatment approach within the 4 participating centers, e.g., different washout periods between medication switch, different intervals of MRI, and clinical investigations. However, as we present a real-world study, the latter limitation, which interferes with data analysis, mainly reflects the clinical situation of most neurologists treating patients with MS.

Considering the growing armamentarium of immunotherapies for patients with MS and the known effects of medication withdrawal and switch during MS disease course, our study, which provides evidence for decision-making processes, may guide physicians throughout clinically challenging treatment options.

\section{Study funding}

No targeted funding reported.

\section{Disclosure}

L. Diem received travel grants from Merck, Biogen, Roche, and Bayer Schweiz. A. Daponte reports no disclosures. O. Findling received compensation for consulting and travel from Bayer, Biogen, Roche, Teva, Sanofi Genzyme, Merck, Allmirall, and Novartis. A. Miclea reports no disclosures. M. Briner received travel grants from Merck and Biogen. A. Salmen received speaker honoraria and/or travel compensation for activities with Almirall Hermal GmbH, Biogen, Merck, Novartis, Roche, and Sanofi Genzyme, none related to this work. R. Gold received speaker's and board honoraria from Biogen Idec, Baxter, Bayer Schering, Chugai Pharmaceuticals, Merck Serono, Novartis, Roche, Sanofi-Aventis, Talecris, and Teva. He also received scientific grant support from Biogen Idec, Bayer Schering, Genzyme, Merck Serono, and Teva. C. Kilidireas has received travel grants and consulting fees from Biogen, Sanofi, Novartis, Roche, Teva, and Serono. A. Chan has received compensation for activities with Actelion, Almirall, Bayer HealthCare, Biogen, Celgene, Genzyme, Merck, Novartis, Sanofi-Aventis, and Teva Neuroscience, all for university research funds, and research support from Biogen, Genzyme, and UCB. M.E. Evangelopoulos has received travel grants and consulting fees from Biogen, Novartis, Genzyme, Teva, Merck, and Roche. R. Hoepner received research and travel grants from Novartis and Biogen Idec. He also received speaker's honoraria from Biogen, Novartis, Merck, and Almirall. Go to Neurology. org/NN for full disclosures.

\section{Publication history}

Received by Neurology: Neuroimmunology \& Neuroinflammation June 17, 2019. Accepted in final form November 22, 2019.

Appendix Authors

\begin{tabular}{|c|c|c|c|}
\hline Name & Location & Role & Contribution \\
\hline Lara Diem, MD & $\begin{array}{l}\text { Inselspital } \\
\text { University Hospital } \\
\text { and University of } \\
\text { Bern, Bern, } \\
\text { Switzerland }\end{array}$ & Author & $\begin{array}{l}\text { Contributed to the } \\
\text { design of the study, } \\
\text { acquisition of data, } \\
\text { analysis and } \\
\text { interpretation of } \\
\text { the data, and } \\
\text { writing and revision } \\
\text { of the manuscript }\end{array}$ \\
\hline
\end{tabular}


Appendix (continued)

\begin{tabular}{|c|c|c|c|}
\hline Name & Location & Role & Contribution \\
\hline $\begin{array}{l}\text { Ariadne } \\
\text { Daponte, MD }\end{array}$ & $\begin{array}{l}\text { Eginition University } \\
\text { Hospital, National } \\
\text { and Kapodistrian } \\
\text { University of } \\
\text { Athens, Athens, } \\
\text { Greece }\end{array}$ & Author & $\begin{array}{l}\text { Contributed to the } \\
\text { acquisition of data } \\
\text { and revised the } \\
\text { manuscript for } \\
\text { intellectual content }\end{array}$ \\
\hline $\begin{array}{l}\text { Oliver Findling, } \\
\text { MD }\end{array}$ & $\begin{array}{l}\text { Cantonal Hospital } \\
\text { Aarau, Aarau, } \\
\text { Switzerland, and } \\
\text { Department of } \\
\text { Neurology, Karl } \\
\text { Landsteiner } \\
\text { University of Health } \\
\text { Sciences, Site Tulln, } \\
\text { Tulln, Austria }\end{array}$ & Author & $\begin{array}{l}\text { Contributed to the } \\
\text { acquisition of data } \\
\text { and revised the } \\
\text { manuscript for } \\
\text { intellectual content }\end{array}$ \\
\hline $\begin{array}{l}\text { Andrei Miclea, } \\
\text { MD }\end{array}$ & $\begin{array}{l}\text { Inselspital } \\
\text { University Hospital } \\
\text { and University of } \\
\text { Bern, Bern, } \\
\text { Switzerland }\end{array}$ & Author & $\begin{array}{l}\text { Contributed to the } \\
\text { acquisition of data } \\
\text { and revised the } \\
\text { manuscript for } \\
\text { intellectual content }\end{array}$ \\
\hline $\begin{array}{l}\text { Myriam Briner, } \\
\text { MD }\end{array}$ & $\begin{array}{l}\text { Inselspital } \\
\text { University Hospital } \\
\text { and University of } \\
\text { Bern, Bern, } \\
\text { Switzerland }\end{array}$ & Author & $\begin{array}{l}\text { Contributed to the } \\
\text { acquisition of data } \\
\text { and revised the } \\
\text { manuscript for } \\
\text { intellectual } \\
\text { content }\end{array}$ \\
\hline $\begin{array}{l}\text { Anke Salmen, } \\
\text { MD }\end{array}$ & $\begin{array}{l}\text { Inselspital } \\
\text { University Hospital } \\
\text { and University of } \\
\text { Bern, Bern, } \\
\text { Switzerland }\end{array}$ & Author & $\begin{array}{l}\text { Contributed to the } \\
\text { interpretation of } \\
\text { the data and the } \\
\text { writing and revision } \\
\text { of the manuscript }\end{array}$ \\
\hline Ralf Gold, MD & $\begin{array}{l}\text { St. Josef Hospital } \\
\text { Ruhr University } \\
\text { Bochum, Bochum, } \\
\text { Germany }\end{array}$ & Author & $\begin{array}{l}\text { Contributed to the } \\
\text { acquisition of data } \\
\text { and revised the } \\
\text { manuscript for } \\
\text { intellectual } \\
\text { content }\end{array}$ \\
\hline $\begin{array}{l}\text { Constantinos } \\
\text { Kilidireas, MD }\end{array}$ & $\begin{array}{l}\text { Eginition University } \\
\text { Hospital, National } \\
\text { and Kapodistrian } \\
\text { University of } \\
\text { Athens, Athens, } \\
\text { Greece }\end{array}$ & Author & $\begin{array}{l}\text { Contributed } \\
\text { significantly to the } \\
\text { data analysis and } \\
\text { digitalization } \\
\text { during the review } \\
\text { process }\end{array}$ \\
\hline
\end{tabular}

Appendix (continued)

\begin{tabular}{|c|c|c|c|}
\hline Name & Location & Role & Contribution \\
\hline $\begin{array}{l}\text { Andrew Chan, } \\
\text { MD }\end{array}$ & $\begin{array}{l}\text { Inselspital } \\
\text { University Hospital } \\
\text { and University of } \\
\text { Bern, Bern, } \\
\text { Switzerland }\end{array}$ & Author & $\begin{array}{l}\text { Contributed to the } \\
\text { interpretation of } \\
\text { the data and the } \\
\text { writing and revision } \\
\text { of the manuscript }\end{array}$ \\
\hline $\begin{array}{l}\text { Maria } \\
\text { Eleftheria } \\
\text { Evangelopoulos, } \\
\text { MD }\end{array}$ & $\begin{array}{l}\text { Eginition University } \\
\text { Hospital, National } \\
\text { and Kapodistrian } \\
\text { University of } \\
\text { Athens, Athens, } \\
\text { Greece }\end{array}$ & Author & $\begin{array}{l}\text { Contributed to the } \\
\text { design of the study, } \\
\text { acquisition of data, } \\
\text { analysis and } \\
\text { interpretation of } \\
\text { the data, and } \\
\text { writing and revision } \\
\text { of the manuscript }\end{array}$ \\
\hline $\begin{array}{l}\text { Robert Hoepner, } \\
\text { MD }\end{array}$ & $\begin{array}{l}\text { Inselspital } \\
\text { University Hospital } \\
\text { and University of } \\
\text { Bern, Bern, } \\
\text { Switzerland }\end{array}$ & Author & $\begin{array}{l}\text { Contributed to the } \\
\text { design of the study, } \\
\text { acquisition of data, } \\
\text { analysis and } \\
\text { interpretation of } \\
\text { the data, and } \\
\text { writing and revision } \\
\text { of the manuscript }\end{array}$ \\
\hline
\end{tabular}

\section{References}

1. Calabresi PA, Radue EW, Goodin D, et al. Safety and efficacy of fingolimod in patients with relapsing-remitting multiple sclerosis (FREEDOMS II): A double-blind, randomised, placebo-controlled, phase 3 trial. Lancet Neurol 2014;13:545-556.

2. Gold R, Kappos L, Arnold DL, et al. Placebo-controlled phase 3 study of oral BG-12 for relapsing multiple sclerosis. N Engl J Med 2012;367:1098-1107.

3. Vollmer B, Ontaneda D, Bandyopadhyay A, et al. Discontinuation and comparative effectiveness of dimethyl fumarate and fingolimod in 2 center. Neurol Clin Practica 2018;8:292-301.

4. Ontaneda D, Nicholas J, Carraro M, et al. Comparative effectiveness of dimethyl fumarate versus fingolimod and teriflunomide among MS patients switching from firstgeneration platform therapies in the US. Mult Scler Relat Disord 2019;27;101-111.

5. Hersh CM, Love TE, Cohn S, et al. Comparative efficacy and discontinuation of dimethyl fumarate and fingolimod in clinical practice at 12-month follow-up. Mult Scler Relat Disord 2016;10:44-52.

6. Prosperini L, Lucchini M, Haggiag S, et al. Fingolimod vs dimethyl fumarate in multiple sclerosis: a real-world propensity score-matched study. Neurology 2018;91:e153-e161.

7. Polman CH, Reingold SC, Banwell B, et al. Diagnostic criteria for multiple sclerosis: 2010 revisions to the McDonald criteria. Ann Neurol 2011;69:292-302.

8. Arzneimittelinformation, Swissmedic. Available at: swissmedicinfo.ch/. Accessed March $1,2011$.

9. EMA-guideline on Adjustment for Baseline Covariates in Clinical Trials, EMA/CHMP/ 295050/2013. https://www.ema.europa.eu/en/documents/scientific-guideline/guideline-adjustment-baseline-covariates-clinical-trials en.pdf.

10. Achtnichts L, Chan A, Czaplinski A, et al. Specific aspects of immunotherapy for multiple sclerosis in Switzerland: A structured commentary. Clin Translational Neurosci 2019;3:1-9. 


\title{
Neurology \\ Neuroimmunology \& Neuroinflammation
}

\author{
Dimethyl fumarate vs fingolimod following different pretreatments: A retrospective \\ study \\ Lara Diem, Ariadne Daponte, Oliver Findling, et al. \\ Neurol Neuroimmunol Neuroinflamm 2020;7; \\ DOI 10.1212/NXI.0000000000000660
}

This information is current as of January 14, 2020

Updated Information \&

Services

References

Subspecialty Collections

Permissions \& Licensing

Reprints including high resolution figures, can be found at:

http://nn.neurology.org/content/7/2/e660.full.html

This article cites 8 articles, 0 of which you can access for free at: http://nn.neurology.org/content/7/2/e660.full.html\#\#ref-list-1

This article, along with others on similar topics, appears in the following collection(s):

Multiple sclerosis

http://nn.neurology.org//cgi/collection/multiple_sclerosis

Information about reproducing this article in parts (figures,tables) or in its entirety can be found online at:

http://nn.neurology.org/misc/about.xhtml\#permissions

Information about ordering reprints can be found online: http://nn.neurology.org/misc/addir.xhtml\#reprintsus

Neurol Neuroimmunol Neuroinflamm is an official journal of the American Academy of Neurology.

Published since April 2014, it is an open-access, online-only, continuous publication journal. Copyright

Copyright (C) 2020 The Author(s). Published by Wolters Kluwer Health, Inc. on behalf of the American

Academy of Neurology.. All rights reserved. Online ISSN: 2332-7812.

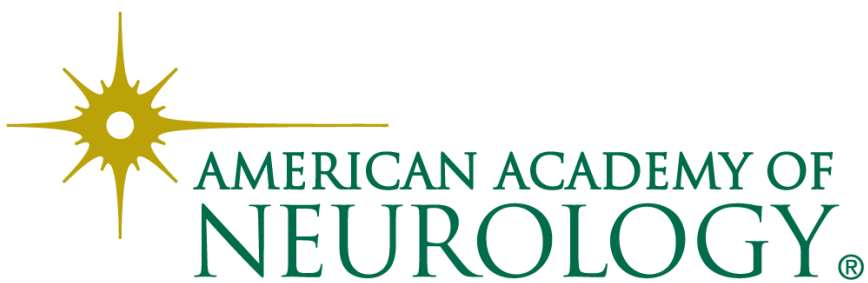

